\title{
Sequential Expression of Macromolecule Biosynthesis and Candicidin Formation in Streptomyces griseus
}

\author{
By PALOMA LIRAS, JULIO R. VILLANUEVA AND \\ JUAN F. MARTIN \\ Instituto de Microbiología Bioquímica, CSIC, Departamento de Microbiología, \\ Facultad de Ciencias, Universidad de Salamanca, Salamanca, Spain
}

(Received 3I March 1977)

\begin{abstract}
Streptomyces griseus did not produce the polyene macrolide antibiotic candicidin during the initial growth phase characterized by rapid RNA synthesis. The absence of candicidin production when RNA or protein synthesis was inhibited by rifampicin or chloramphenicol suggests a transcriptionally controlled late formation of the candicidin synthases. Phosphate levels in the medium control the rate of DNA, RNA and protein synthesis. Depletion of phosphate appears to trigger the onset of candicidin synthesis after a drastic reduction of the rate of RNA synthesis. Changes in the ATP pool during the fermentation suggest that ATP may be the intracellular effector controlling the onset of antibiotic synthesis.
\end{abstract}

\section{INTRODUCTION}

The 'late' expression of the synthesis of antibiotics and other secondary metabolites following intensive growth is a well-known phenomenon. It is equivalent to a differentiation process in which genetic information coding for growth and for antibiotic biosynthesis is sequentially expressed. In broad terms, two types of control mechanism are thought to be responsible, i.e. the antibiotic synthases are formed during growth but remain inhibited during the growth phase (post-translational control) or they are formed in a late phase subsequent to growth (transcriptional control). In most cases studied, the enzymes involved in antibiotic synthesis are repressed during the growth phase (Walker \& Hnilica, 1964; Pruess \& Johnson, 1967; Gallo \& Katz, 1972). Although the intracellular factors that trigger onset of antibiotic synthesis are unknown, catabolite regulation (Gallo \& Katz, 1972), inducer accumulation (Krupinski, Robbers \& Floss, 1976) and phosphate (or ATP) control (Martín, 1976) have been proposed as control mechanisms.

The biosynthesis of many antibiotics is controlled by inorganic phosphate (Weinberg, 1974; Martín, 1976). In particular, the formation of the polyene macrolide antibiotic candicidin is a very suitable model system for the study of the control mechanisms involved in the onset of antibiotic synthesis because of its high sensitivity to phosphate (Liu, McDaniel \& Schaffner, 1975; Martín \& Demain, 1976). The possible involvement of ATP as the intracellular effector controlling antibiotic synthesis is suggested by the work of Janglova, Suchy \& Vanek (1969) and J. F. Martín, P. Liras \& A. L. Demain (unpublished observations). Since oxygen uptake and DNA synthesis follow diphasic patterns in cultures synthesizing polyene macrolide antibiotics (Martín \& McDaniel, 1974; Martín \& McDaniel, I975a) it was of interest to study the relationship between intracellular ATP concentrations and the formation of the antibiotic as well as the synthesis of RNA and protein. The results obtained in this work indicate that formation of candicidin synthases occurs after a rapid growth phase characterized by a high rate of RNA synthesis and is probably mediated by the intracellular ATP level. 


\section{METHODS}

Micro-organisms and growth conditions. Streptomyces griseus IMRU3570, the strain producing candicidin, was grown in a medium supporting high antibiotic production which contained soya peptone $\left(25 \mathrm{~g}^{\mathbf{1}^{-1}}\right)$, glucose $\left(65 \mathrm{~g}^{-1}\right)$ and zinc sulphate $(0.5 \mathrm{~mm})$ (Martin \& McDaniel, 1975a). The cultures were incubated at $32{ }^{\circ} \mathrm{C}$ in triple-baffled $250 \mathrm{ml}$ flasks, containing $50 \mathrm{ml}$ of medium, in a Gallenkamp orbital shaking incubator operating at $225 \mathrm{rev}$. $\mathrm{min}^{-1}$. The production flasks were inoculated with $5 \mathrm{ml}$ of a $24 \mathrm{~h}$ inoculum grown in medium containing yeast extract $\left(10 \mathrm{~g} \mathrm{l}^{-1}\right)$ and glucose $\left(\log \mathrm{I}^{-1}\right)$.

Synthesis of candicidin was determined as described previously (Martín \& McDaniel 1975a). DNA content was measured in perchloric acid extracts after lipid and protein removal, according to Schneider (1957).

Determination of $R N A$ and protein synthesis. Incorporation of $\left[2{ }^{14} \mathrm{C}\right]$ uracil $\left(59 \mathrm{Ci} \mathrm{mol}^{-1}\right)$ into $5 \%(\mathrm{w} / \mathrm{v})$ cold trichloroacetic acid (TCA)-precipitable macromolecules was done as previously described (Martín \& McDaniel, 1975b; Martin \& Demain, 1976) except that $0.1 \mu \mathrm{Ci}$ of [ ${ }^{14} \mathrm{C}$ ] uracil was added to $0.25 \mathrm{ml}$ of culture supplemented with $2 \mathrm{mM}$ unlabelled uracil. Incorporation of the ${ }^{14} \mathrm{C}$-labelled amino acid mixture $\left(226 \mathrm{Ci} \mathrm{mol}^{-1}\right.$ ) into $5 \%$ cold TCA-precipitable material was done using $0.025 \mu \mathrm{Ci}$ in $0.25 \mathrm{ml}$ of culture, supplemented with $0.05 \mathrm{mg}$ unlabelled Casamino acids $\mathrm{ml}^{-1}$ (Difco). When measuring incorporation of labelled amino acids into protein, charged aminoacyl-tRNA was removed by solubilization in $5 \%$ TCA at $90^{\circ} \mathrm{C}$ for $20 \mathrm{~min}$. Pulses of $10 \mathrm{~min}$ were used for RNA and protein synthesis determinations.

Preparation of phosphate-limited resting cells was carried out as previously described (Martín \& McDaniel, 1975b; Martín \& McDaniel, 1976).

Determination of phosphate utilization. Labelled phosphate $\left[95 \mathrm{Ci}\left(\mathrm{mg}\right.\right.$ phosphate) $\left.{ }^{-1}\right]$ was added at inoculation time to control flasks and to flasks supplemented with $10 \mathrm{~mm}$-unlabelled inorganic phosphate. Samples $(250 \mu \mathrm{l})$ of the culture were filtered through Whatman GF/A glass-fibre filters and the filtrates were collected. Intracellular radioactive phosphate was measured on the dried filters, and extracellular radioactivity was determined on samples of the filtrates. Counting was done in a Packard Tricarb 3320 liquid scintillation counter. Colour quenching was corrected, if required, by the channels ratio method.

ATP determination. The method for determination of ATP was similar to that of Ball \& Atkinson (1975). Samples ( $1 \mathrm{ml}$ ) were rapidly pipetted (within $15 \mathrm{~s}$ ) into $0.2 \mathrm{ml}$ of ice-cold $35 \%(\mathrm{v} / \mathrm{v})$ perchloric acid in order to 'freeze' the nucleotide pools prior to analysis. After $2 \mathrm{~min}$ at $0^{\circ} \mathrm{C}$, the extracts were rapidly frozen in liquid nitrogen and kept frozen until assayed. After thawing, the extracts were thoroughly mixed and centrifuged at $10000 \mathrm{~g}$ for $5 \mathrm{~min}$. The supernatant fluids were neutralized with $0.4 \mathrm{ml}$ of $2.6 \mathrm{M}-\mathrm{KOH}$. The final $\mathrm{pH}$ was adjusted to 7.4 with $\mathrm{I} 00 \mu \mathrm{l}$ of $\mathrm{I} \mathrm{M}$-phosphate buffer $\mathrm{pH} 7.4$. After at least $30 \mathrm{~min}$ at $0^{\circ} \mathrm{C}$, the $\mathrm{KClO}_{4}$ precipitate was removed by centrifugation. Recovery of externally added ATP was $85 \%$. ATP was determined by the luciferase reaction using the Packard Tricarb 3320 scintillation counter as a photometer (Stanley \& Williams, 1969). One vial of crystalline luciferin-luciferase reagent (DuPont de Nemours and Co.) was dissolved in $3 \mathrm{ml}$ of morpholinopropane sulphonic acid buffer (MOPS) pH 7*4. Before the enzymic reaction, the enzyme solution was diluted $1 / 10$ into distilled water. A cuvette containing $200 \mu$ l of diluted enzyme solution, $500 \mu \mathrm{l}$ of assay buffer (100 mM-glycine/ $\mathrm{NaOH}$ buffer $\mathrm{pH} 7.4$ ) and $500 \mu \mathrm{l}$ of $15 \mathrm{mM}_{-1} \mathrm{MgCl}_{2}$ was placed in the belt of the scintillation counter and 10 to $100 \mu \mathrm{l}$ of ATP extract were rapidly injected into the vial at the time it was entering the counting chamber. Standard ATP solutions, in the range $0 \cdot 1$ to Io $\mu \mathrm{M}$-ATP (Io pmol to I $\mathrm{nmol}$ per $100 \mu \mathrm{l}$ sample), gave a reproducible linear response. Extracellular ATP, measured after Millipore filtration of culture broths, was always two orders of magnitude lower than the intracellular levels and was usually undetectable.

Chemicals. Chloramphenicol, rifampicin and ATP were purchased from Sigma. Luciferase was a product of DuPont de Nemours and $\mathrm{Co}$. [2-14 $^{-1}$ Uracil $\left(59 \mathrm{Ci} \mathrm{mol}^{-1}\right)$ and [ $\left.{ }^{32} \mathrm{P}\right]$ orthophosphate [95 $\mathrm{Ci}\left(\mathrm{mg}\right.$ phosphate) $\left.{ }^{-1}\right]$ were from The Radiochemical Centre, Amersham. Uniformly ${ }^{14} \mathrm{C}$-labelled L-amino acid mixture $(226 \mathrm{Ci}$ $\mathrm{mol}^{-1}$ ) was purchased from New England Nuclear Corporation. All reagents were of analytical grade.

\section{RESULTS}

\section{Time sequence of macromolecule biosynthesis}

The kinetics of the rate of RNA synthesis indicated a clear-cut separation of two phases, the growth phase (trophophase) and the production phase (idiophase) (Fig. I). A high rate of RNA synthesis occurred during the first $15 \mathrm{~h}$ of fermentation and then decreased rapidly. No antibiotic was synthesized during the phase of rapid RNA synthesis. An increase in the content of DNA was also observed during this phase (Martin \& McDaniel, 1975a).

The increase in the rate of protein synthesis lagged behind the increase in RNA synthesis, 


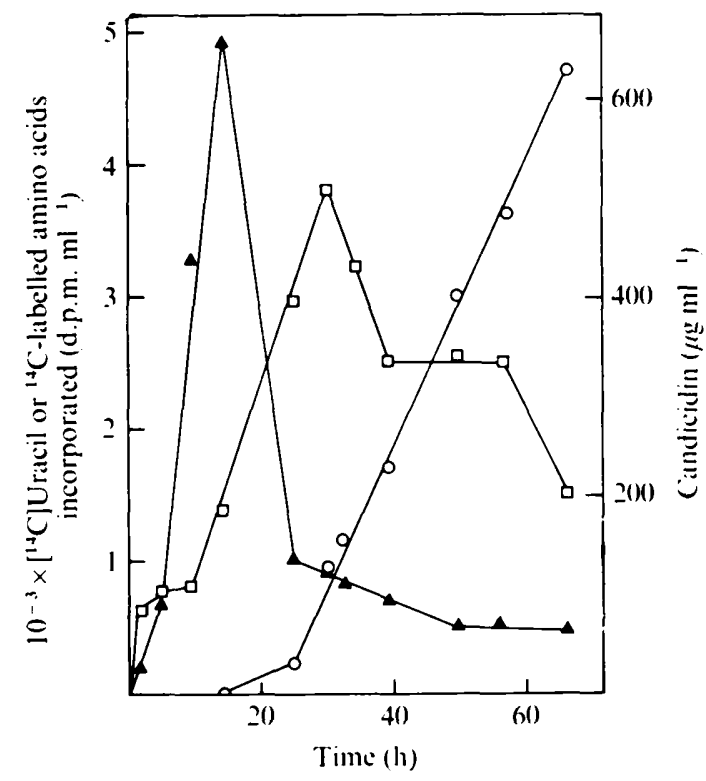

Fig. I

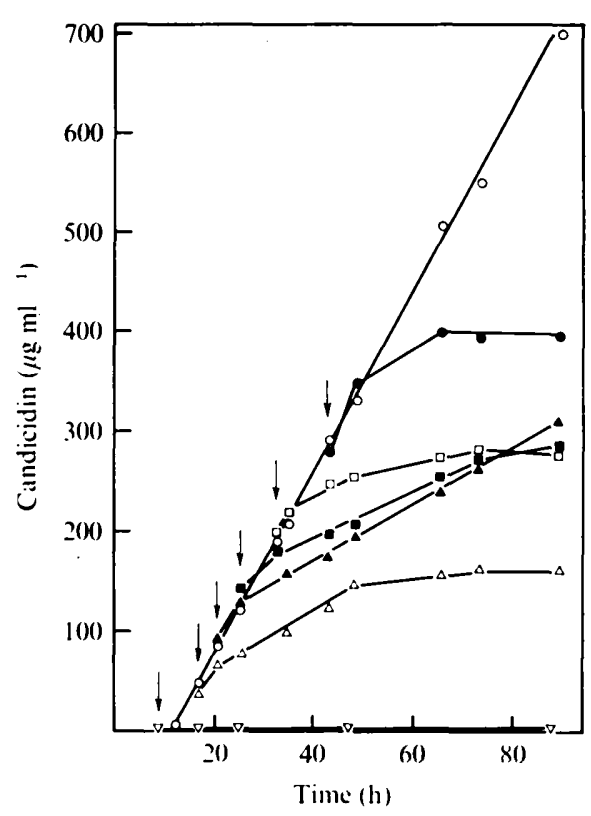

Fig. 2

Fig. I. Kinetics of the synthesis of $\mathrm{RNA}^{-}$(IO min pulses) ( $\Delta$ ), protein (10 min pulses) ( $\square$ ) and candicidin $(\bigcirc)$.

Fig. 2. Effect of chloramphenicol $\left(100 \mu \mathrm{g} \mathrm{ml}^{-1}\right)$ on candicidin synthesis. $\bigcirc$, Control; chloramphenicol added at (h): $\nabla, 10 ; \triangle, \mathrm{I} 8 ; \Delta, 20 ; \square, 25 ; \square, 32 ; 0,43$. Similar curves were obtained with rifampicin at $10 \mu \mathrm{g} \mathrm{ml}^{-1}$.

reaching a maximum rate at $30 \mathrm{~h}$ and decreasing slowly thereafter (Fig. I). Thus, considerable protein synthesis occurred during the phase of antibiotic production, whereas there was little RNA turnover in this phase. Total dry weight also increased during the idiophase, this increase representing mainly storage materials plus antibiotic (Martín \& McDaniel, 1975a).

Antibiotic production began at about $20 \mathrm{~h}$, following the rapid decrease in RNA synthesis. Thereafter, antibiotic production was linear for at least $40 \mathrm{~h}$.

\section{'Late' formation of antibiotic synthases}

The late onset of candicidin synthesis may be due to a delayed formation of candicidin synthases or to a release from inhibition of growth-associated antibiotic synthases. We checked these two possibilities by studying the effect of rifampicin and chloramphenicol on candicidin synthesis. At the concentration used $\left(100 \mu \mathrm{g} \mathrm{ml}^{-1}\right)$, chloramphenicol completely inhibited protein synthesis within $40 \mathrm{~min}$ of its addition but did not produce lysis of the culture. Rifampicin was used at $10 \mu \mathrm{g} \mathrm{ml}^{-1}$ which completely inhibited RNA synthesis within $40 \mathrm{~min}$; higher concentrations produced cell lysis. We found that little or no candicidin was formed if chloramphenicol or rifampicin was added before $18 \mathrm{~h}$, but increasing amounts of candicidin accumulated when either RNA or protein synthesis was inhibited at $18,20,25,32$ and $43 \mathrm{~h}$. The results presented in Fig. 2 show the effect of chloramphenicol but the results with rifampicin were not significantly different. Both chloramphenicol and rifampicin permitted a residual synthesis of candicidin for a few hours, probably due to the existing pool of mRNA for candicidin synthases and the pool of pre-formed synthases.

These results suggest that antibiotic synthases are formed late. However, it could be that the enzymes formed early were inhibited by the phosphate in the medium until this had been depleted. Moreover, addition of chloramphenicol or rifampicin to the batch culture may 


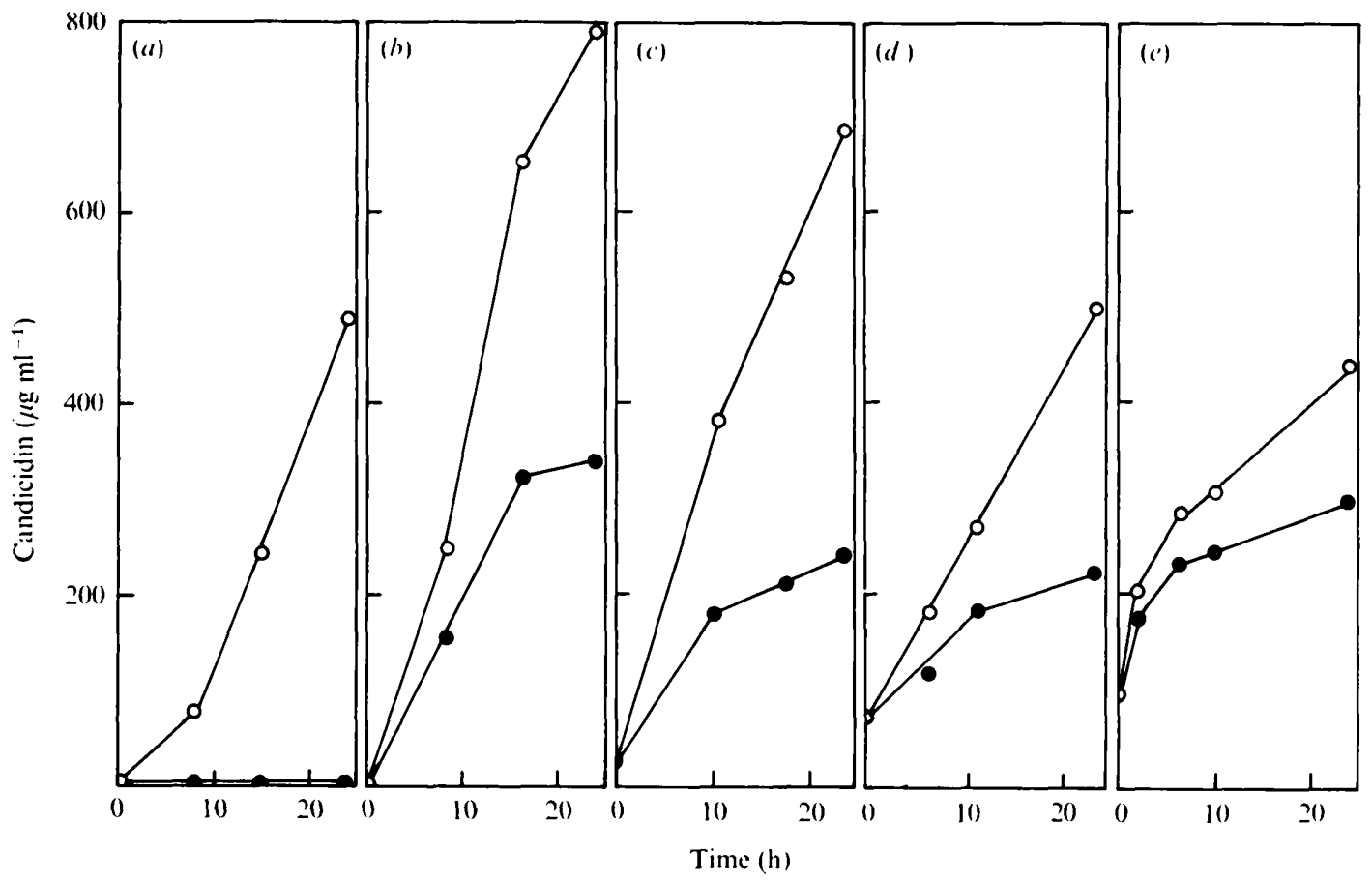

Fig. 3. Candicidin synthesis by phosphate-limited resting cell suspensions prepared from batch fermentations at (a) $9 \mathrm{~h},(b) 16 \mathrm{~h},(c) 24 \mathrm{~h},(d) 36 \mathrm{~h}$ and (e) $60 \mathrm{~h}$. $\bigcirc$, Control; $\bigcirc$, medium supplemented with chloramphenicol at $100 \mu \mathrm{g} \mathrm{ml}^{-1}$.

have retarded the rate of phosphate utilization. To check this possibility, phosphate-limited resting cells were prepared at different times during the fermentation. The synthesis of candicidin by phosphate-limited resting cells was compared with candicidin production by similar cells in which protein synthesis was inhibited by chloramphenicol. No candicidin synthesis by phosphate-limited cells was observed in chloramphenicol-treated cells prepared from a $9 \mathrm{~h}$ batch culture (Fig. $3 a$ ). Control cells without chloramphenicol were derepressed for candicidin synthesis after suspension in the phosphate-free medium, even though there was no candicidin at $9 \mathrm{~h}$ in the batch fermentation. In phosphate-limited cells prepared from a $16 \mathrm{~h}$ batch culture (Fig. $3 b$ ) some candicidin was produced in chloramphenicol-treated cells, which indicates that at this time some candicidin synthases were already formed, even though they were not expressed in the batch culture. Higher rates of synthesis of candicidin by chloramphenicol-treated cells obtained after 24,36 or $60 \mathrm{~h}$ of fermentation suggest that at this time a large part of the candicidin synthases are already formed (Fig. $3 c, d, e$ ). It seems, therefore, that no candicidin synthases are formed in the first hours of fermentation, suggesting transcriptional control of its 'late' formation.

\section{Control by phosphate of macromolecular synthesis and candicidin production}

To study whether phosphate is involved in the time-sequence of macromolecular synthesis and antibiotic production, fermentations were carried out with and without added phosphate (IO mM). In the soya peptone medium, $5 \mathrm{mg}$ cell dry $\mathrm{wt} \mathrm{ml}^{-1}$ was reached in $60 \mathrm{~h}$, accompanied by candicidin production amounting to about $600 \mu \mathrm{g} \mathrm{ml}^{-1}$ (Fig. 4). In the presence of added phosphate, growth (as cell dry weight) was doubled but no candicidin was formed (Fig. 4). Addition of 10 mM-phosphate also resulted in an increased rate of RNA synthesis, protein synthesis and DNA content (Fig. 5). 

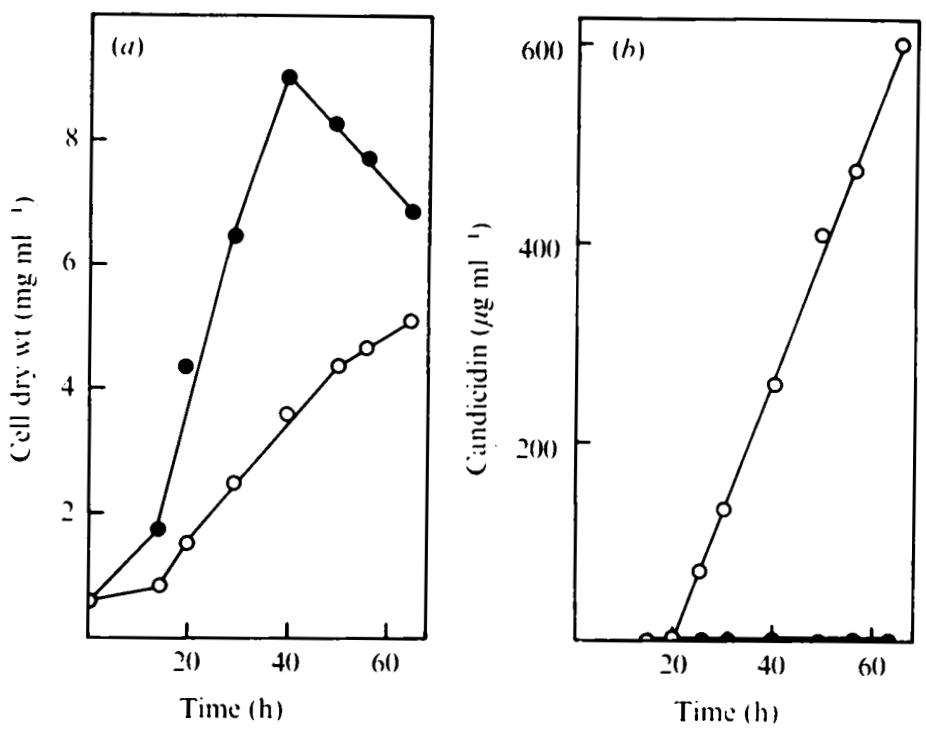

Fig. 4. Effect of phosphate on (a) cell dry weight and $(b)$ candicidin synthesis. $\bigcirc$, Control; medium supplemented with ro mM-potassium phosphate at inoculation time.
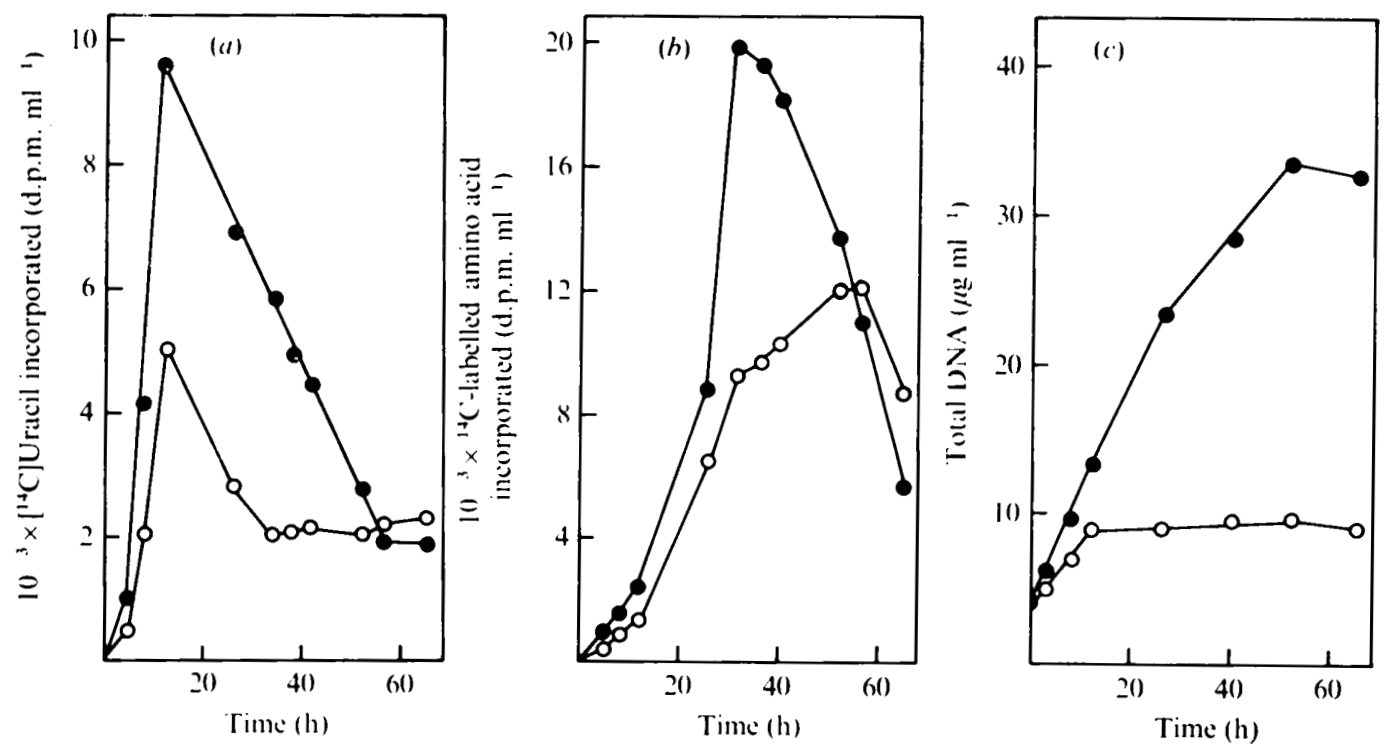

Fig. 5. Effect of phosphate on the synthesis of (a) RNA (Io min pulses), (b) protein (10 min pulses) and (c) DNA. $\bigcirc$, Control; $\bullet$, medium supplemented with 10 mM-potassium phosphate at inoculation time.

Phosphate depletion and onset of candicidin synthesis

Martin (1976) suggested that phosphate might be exhausted before the onset of antibiotic synthesis. We followed the uptake of [ $\left.{ }^{32} \mathrm{P}\right]$ phosphate in control cultures (unsupplemented, Fig. 6a) and in cultures supplemented with Io mM-phosphate (Fig. 6b). [ $\left.{ }^{32} \mathrm{P}\right] \mathrm{Phosphate}$ was rapidly utilized in control cultures. Only small amounts of extracellular phosphate remained in the broth at $13 \mathrm{~h}, 2$ to $3 \mathrm{~h}$ before the onset of candicidin synthesis in this experiment. This was also the time when candicidin synthases start to be formed (Figs 2 and 3). [ $\left.{ }^{32} \mathrm{P}\right] \mathrm{Ph}$ osphate is accumulated as intracellular phosphate in control cultures. Extracellular phosphate levels 


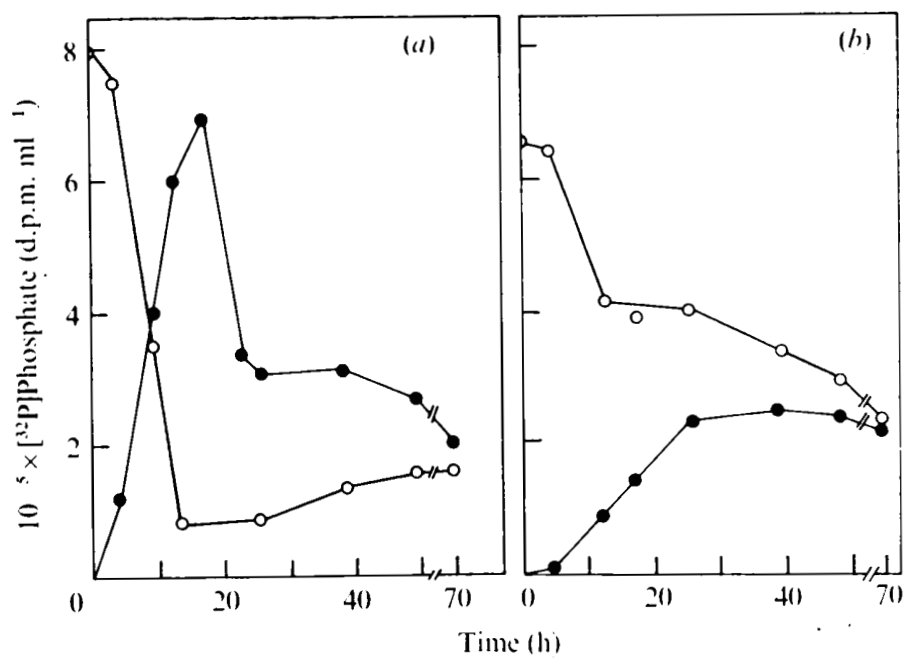

Fig. 6. Extra- and intracellular phosphate in control and phosphate-supplemented batch fermentation. $(a)$ Control fermentation and $(b)$ medium supplemented with $10 \mathrm{mM}$-phosphate. Intracellular phosphate; $\bigcirc$, extracellular phosphate.

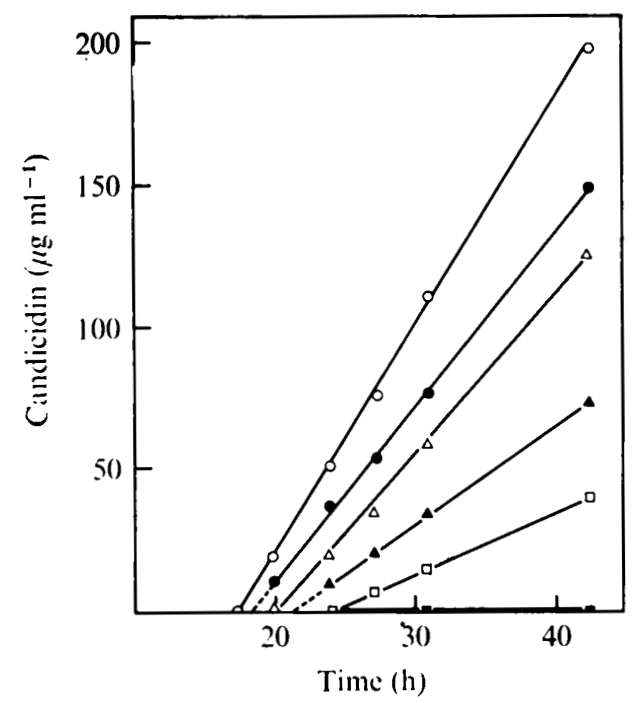

Fig. 7

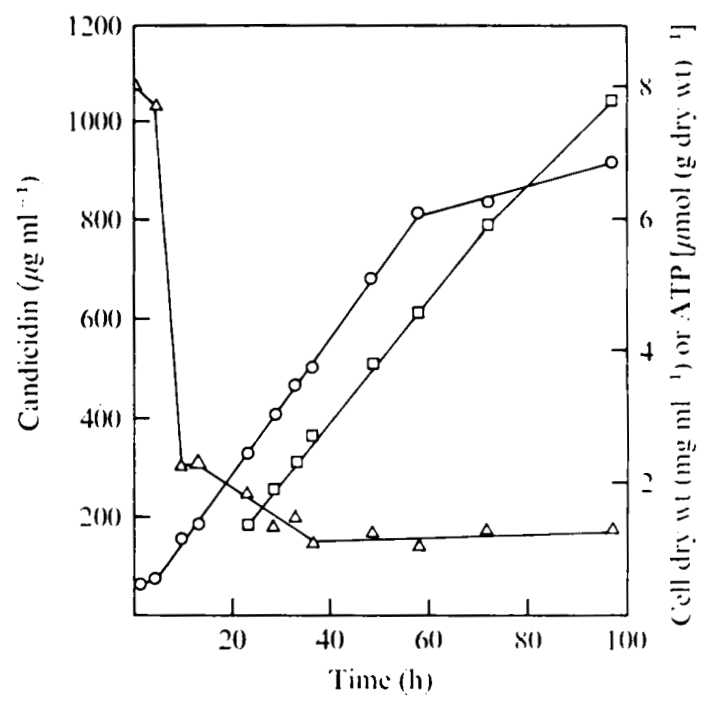

Fig. 8

Fig. 7. Onset of candicidin synthesis in media supplemented with increasing phosphate concentrations. $\bigcirc$, Control; phosphate added at (mM): $\bullet, 1 ; \Delta, 2 ; \Delta, 3 ; \square, 5 ; \square, 10$.

Fig. 8. Changes in the intracellular ATP pool during candicidin batch fermentation inoculated with growing mycelium. $\triangle$, ATP; $\bigcirc$, cell dry weight; $\square$, candicidin.

remained quite low during most of the production phase. In cultures supplemented with Io mM-phosphate, there was fast phosphate utilization during rapid growth, followed by slower utilization thereafter. Extracellular levels of phosphate in supplemented cultures were much higher throughout the fermentation.

If the depletion of phosphate triggers the onset of candicidin synthesis, it would be expected that cultures supplemented with increasing concentrations of phosphate would be depleted later and later, thus delaying the onset of candicidin synthesis. This was found to be the case (Fig. 7). 

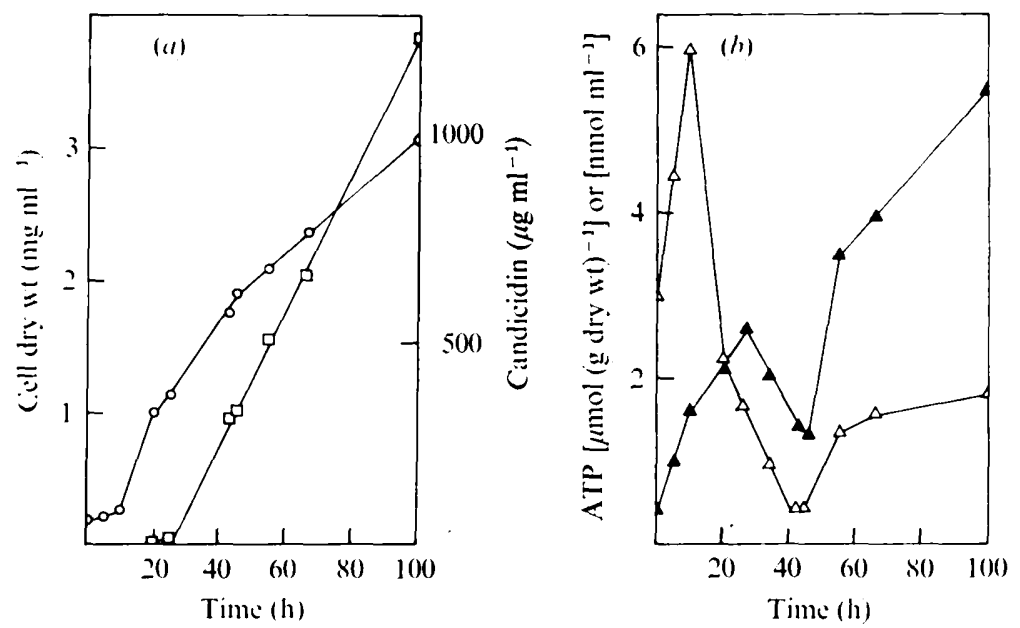

Fig. 9. Changes in the intracellular ATP pool during candicidin batch fermentation inoculated with spores. (a) $\bigcirc$, Cell dry weight; $\square$, candicidin. (b) ATP concentration calculated as $\mu \mathrm{mol}$ (g dry $\mathrm{wt}^{-1}(\Delta)$ or $\mathrm{nmol} \mathrm{ml}^{-1}(\Delta)$.

\section{Intracellular ATP levels and onset of candicidin synthesis}

As a control in intermediary metabolism, ATP is a potential effector in phosphatemediated control of candicidin synthesis. To study this possibility, we followed intracellular ATP levels during candicidin fermentation (Fig. 8). The ATP level per $g$ of cells decreased sharply during the first io $\mathrm{h}$ of fermentation, before the onset of antibiotic synthesis. The ATP generated via rapid respiration at this time (Martín \& McDaniel, 1975a) was actively used in the synthesis of macromolecules (RNA and protein) and thus decreased rapidly. As long as phosphate does not become limiting, the ATP pool is partially replenished, but after phosphate becomes limiting, ATP pools are kept necessarily low and the synthesis of macromolecules is severely limited. The level of the ATP pool remained at a very low level throughout the production phase.

The high ATP level immediately after inoculation of the production medium reflects the ATP pool of cells actively growing in the inoculum medium. In order to speed up antibiotic production, fermentations are usually inoculated with a heavy, fast-growing inoculum to shorten the trophophase. Therefore, to get a better understanding of the role of ATP, we inoculated the production medium with spores (Fig. 9). The rapid growth phase lasted for about $30 \mathrm{~h}$ under these conditions and antibiotic synthesis started after $25 \mathrm{~h}$. When expressed per unit of cell dry weight, the ATP pool increased during the lag phase and decreased sharply during growth prior to the onset of antibiotic synthesis (Fig. 9); it then reached a rather low steady-state level during the production phase. Thus, independently of the type of inoculum used, ATP levels appear to be high during growth and low during the phase of antibiotic production.

\section{DISCUSSION}

The results of Fig. I confirm earlier results obtained in fermenters where a rapid increase in respiration rate and of DNA content was observed during the rapid growth phase (Martín \& McDaniel, 1975a). The increase in the rate of RNA synthesis during the period of non-limited growth followed by the rapid decrease before the onset of antibiotic synthesis, suggest a sequential expression, first of genetic information coding for biosynthesis of macromolecules and then for candicidin production. Similarly, a drastic decline in RNA synthesis has been observed in Streptomyces orientalis at the initiation of vancomycin production (Mertz \& Doolin, 1972) and in Streptomyces antibioticus before the beginning 
of actinomycin formation (Jones \& Weissbach, I970; Jones, 1975). This decrease in RNA synthesis is manifested as a general decrease of the major ribosomal RNA species. However, the changes in RNA could have been due either to a decreased rate of RNA synthesis or to increased degradation (Jones, 1975). Our data obtained by pulse-labelling experiments on in vivo RNA synthesis (Fig. I) suggest that the changes in RNA are mainly due to decreased de novo RNA synthesis after $15 \mathrm{~h}$ of fermentation.

Candicidin synthases were formed only after $18 \mathrm{~h}$ of fermentation (see Figs 2 and 3 ). Thus, formation of antibiotic synthases appears to be repressed during the rapid growth phase. Similar control at the transcription level has been described in the late formation of several antibiotic-synthesizing enzymes (Walker \& Hnilica, 1964; Pruess \& Johnson, 1967; Matteo et al., 1975; Gallo \& Katz, 1972; Matern, Brillinger \& Pape, 1973). The results of Fig. 4 confirm previous results indicating that phosphate addition (IO mM) completely inhibits antibiotic synthesis and greatly increases cell dry weight.

The formation of antibiotic synthases following a decrease in the rate of RNA synthesis might indicate a transcriptional control, e.g. by modification of the template specificity of the RNA polymerase, as occurs in the control of late expression of sporulation genes (Losick \& Sonenshein, 1969). Changes in the structure of the sigma subunit of the RNA polymerase have been postulated to alter the template specificity during sporulation.

Extracellular phosphate depletion occurred at the same time as the onset of candicidin synthesis (Fig. 6). In support of phosphate-mediated control of antibiotic synthesis is the fact that the onset occurred later at higher concentrations of phosphate (Fig. 7). A similar result was described by Mertz \& Doolin (1972), i.e. the presence of excess phosphate delayed the synthesis of vancomycin until $96 \mathrm{~h}$ of fermentation. Moreover, phosphate addition to a candicidin-producing culture resulted in an immediate inhibition of candicidin synthesis (Liu et al., 1975; Martín \& Demain, 1976).

Some clues as to how phosphate can control differential expression of antibiotic synthesis can be derived from the work of Zilling et al. (1975) on the phosphorylation of DNAdependent RNA polymerase of $E$. coli by a phage $\mathrm{T}_{7}$-induced protein kinase. The $\beta^{\prime}$ subunit of $E$. coli RNA polymerase (and to a lesser extent the $\beta$ subunit) is phosphorylated and its activity is lost. Phosphorylation of host RNA polymerase seems to be required for the termination of early transcription of phage $T_{7}$.

Whether the intracellular pool of ATP is the effector mediating the phosphate effect has not been definitively established although the results of Figs 8 and 9 provide some evidence in support of this mechanism. Moreover, phosphate addition to candicidin-producing cultures resulted in an immediate two to threefold increase in the ATP pool level, and simultaneous inhibition of antibiotic synthesis (Martín, 1976; J. F. Martín, P. Liras and A. L. Demain, unpublished observations).

Several other reports point to the involvement of ATP in controlling the onset of antibiotic production. This was first suggested by Silaeva et al. (1965) and Janglova et al. (1969). They reported that ATP levels were lower in high-producing strains than in low-producing strains of Bacillus brevis and Streptomyces aureofaciens. A recent report of Fynn \& Davison (I976) also points to the possible involvement of ATP in the regulation of antibiotic biosynthesis. 


\section{REFERENCES}

Ball, W. J. \& Atkinson, D. E. (1975). Adenylate energy charge in Saccharomyces cerevisiae during starvation. Journal of Bacteriology 121, 975-982.

FynN, G. H. \& Davison, J. A. (1976). Adenine nucleotide pool and energy charge during growth of a tyrothricin-producing strain of Bacillus brevis. Journal of General Microbiology 94, 68-74.

Gallo, M. \& KaTZ, E. (1972). Regulation of secondary metabolite biosynthesis: catabolite repression of phenoxazinone synthase and actinomycin formation by glucose. Journal of Bacteriology rog, 659-667.

Janglova, Z., Suchy, J. \& VANek, Z. (1969). Regulation of biosynthesis of secondary metabolites. VII. Intracellular ATP concentration in Streptomyces aureofaciens. Folia microbiologica I4, 208-210.

JoNES, G. H. (1975). Ribonucleic acid synthesis in Streptomyces antibioticus. Stable ribonucleic acid species synthesized by young and old cells. Biochemical and Biophysical Research Communications 63, 469-475.

JoNes, G. H. \& WeissbaCh, H. (1970). RNA metabolism in Streptomyces antibioticus. Effect of 5 -fluorouracil on the appearance of phenoxazinone synthetase. Archives of Biochemistry and Biophysics 137, 558-573.

KrUPinSKI, V. M., Robbers, J. E. \& Floss, H. G. (1976). Physiological study of ergot: induction of alkaloid synthesis by tryptophan at the enzymatic level. Journal of Bacteriology 125, I 58-165.

Liu, C. M., McDaniel, L. E. \& Schaffner, C. P. (1975). Factors affecting the production of candicidin. Antimicrobial Agents and Chemotherapy 7, 196-202.

Losick, R., \& Sonenshein, A. L. (I969). Change in the template specificity of Bacillus subtilis RNA polymerase during sporulation. Nature, London 224, 35-37.

Martín, J. F. (1976). Phosphate regulation of gene expression in candicidin biosynthesis. In Microbiology 1976, pp. 548-552. Edited by D. Schlessinger. Washington D.C.: American Society for Microbiology.

Martín, J. F. \& Demain, A. L. (1976). Control by phosphate of candicidin production. Biochemical and Biophysical Research Communications 71, I 103-I IO9.

Martín, J. F. \& McDaniel, L. E. (1974). The submerged culture production of the polyene antifungal antibiotics candicidin and candihexin. Developments in Industrial Microbiology 15, 324-337.

Martín, J. F. \& McDaniel, L. E. (I975a). Kinetics of biosynthesis of polyene macrolide antibiotics in batch cultures: cell maturation time. Biotechnology and Bioengineering 17, 925-938.

Martín, J. F. \& McDaniel, L. E. (I975b). Specific inhibition of candicidin biosynthesis by the lipogenic inhibitor cerulenin. Biochimica et biophysica acta 4II, I86-194.

Martín, J. F. \& McDaniel, L. E. (1976). Biosynthesis of candicidin by phosphate-limited resting cells of Streptomyces griseus. European Journal of Applied Microbiology 3, 135-I 44.

Matern, H., Brillinger, G. U. \& PAPE, H. (1973). Metabolic products of microorganisms. II 4 . Thymidine diphospho-D-glucose oxidoreductase from Streptomyces rimosus. Archives of Microbiology 88, 37-48.

Matteo, C. C., Glade, M., Tanaka, A., Piret, J. \& Demain, A. L. (1975). Microbiological studies on the formation of gramicidin $S$ synthetases. Biotechnology and Bioengineering 17 , I 29-I42.

MerTZ, F. P. \& Doolin, L. E. (1972). The effect of inorganic phosphate on the biosynthesis of vancomycin. Canadian Journal of Microbiology 19, 263-270.

Pruess, D. L. \& Johnson, M. J. (1967). Penicillin acyltransferase in Penicillium chry'sogenum. Journal of Bacteriology 94, I 502-1 508.

SCHNEIDER, W. C. (1957). Determination of nucleic acids in tissues by pentose analysis. Methods in Enzymology III, 680-684.

Silaeva, S. A., Glazer, V. M., Shestakov, S. V. \& Prokofiev, M. A. (1965). Nucleotides of Bacillus brevis G.B. cells producing and non-producing gramicidin S. Biokhimiya 30, 947-955.

Stanley, P. E. \& Williams, S. G. (I969). Use of the liquid scintillation spectrometer for determining adenosine triphosphate by the luciferase enzyme. Analytical Biochemistry 29, 38 I-392.

WAlker, J. B. \& Hnilica, V.S. (I964). Development changes in arginine. $X$. Amidino transferase activity in streptomycin-producing strains of Streptomyces. Biochimica et biophysica acta 89, 473-482.

WeINBERG, E. D. (1974). Secondary metabolism. Control by temperature and inorganic phosphate. Developments in Industrial Microbiology 15, 70-81. Zilling, W., Fujiki, H., Blum, W., Janekovic, D., Schweiger, M., Rahmsdorf, H. J., Ponta, H. \& HIRSCH-KAUfFMANN, M. (1975). In vivo and in vitro phosphorylation of DNA-dependent RNA polymerase of Escherichia coli by bacteriophage $\mathrm{T}_{7}$-induced protein kinase. Proceedings of the National Academy of Sciences of the United States of America 72, 2506-2510. 